\title{
Race, Culture and Political Exclusion/Inclusion: \\ The Cases of Australia and New Zealand \\ Sukari Ivester, $\mathrm{PhD}$ \\ Assistant Professor, Department of Sociology \\ California State University,East Bay \\ 25800 Carlos Bee Bloulevard Hayward, CA 94542
}

\section{ABSTRACT}

This article presents a comparison between Australia and New Zealand and the extent to which exclusionary and incorporationist dynamics became dominant in the material practices and political discourses that governed the ethnoracial conflicts in each society. It is argued that formative historical processes led to an overall stronger exclusionary trend in Australia, expressed in the formation of two distinct societies, as compared to a stronger incorporationist trend in New Zealand, expressed in the formation of one internally differentiated and highly inegalitarian society. The task of this historical analysis is to explain why this turned out to be the case. It is argued that two analytical factors account for the divergent courses taken by the two societies in question: (1) the differing capacities of the indigenous people to respond to and shape the process of group encounter and conflict; and (2) the strategies adopted by settler and colonial forces in pursuit of their interests. These analytical factors provide a framework for ultimately discussing the historical processes of state formation in both Australian and New Zealand societies.

\section{Key words}

race relations; inter-group contact; Australia; New Zealand; aboriginal populations; state formation.

\section{Academic Discipline And Sub-Disciplines}

History; Sociology

TYPE (METHOD/APPROACH)

Historical Inquiry

\section{Council for Innovative Research}

Peer Review Research Publishing System

Journal: Journal of Social Sciences Research

Vol. 6 , No. 1

Jssreditor.cir@gmail.com

www.jssronline.com 


\section{INTRODUCTION}

Societies vary considerably in their degree of racial and ethnic antagonism with places such as Brazil and Hawaii often regarded as relatively low in conflict, while the United States and South Africa are considered high in conflict. Scores of variables have been identified to account for the differences: the religion of the dominant group; whether the groups who migrate are dominant or subordinate; hierarchies of race ${ }^{i}$; and an inherent tradition of ethnocentrism. Several writers have attempted to integrate or systematize these themes (e.g. Lieberson, 1961; Mason 1970; Noel, 1968; Schermerhorn, 1970, van de Berge, 1966). However, the view taken in much of the literature on intergroup contact needs to expand to include rigorous analyses of the in subaltern side of the contact. The cases of Australia and New Zealand illustrate the necessity of taking into account the characteristics and capacities of the subaltern, in this case, indigenous groups, in addition to those of dominant groups, in order to engage in comprehensive theoretical analysis of intergroup contact.

The central thread of the present comparison between Australia and New Zealand is the extent to which either exclusionary or incorporationist dynamics became dominant in the material practices and political discourses that governed the ethno-racial conflicts in each society. It is argued that formative historical processes have led to an overall stronger exclusionary trend in Australia, expressed in the formation of two distinct societies, as compared to a stronger incorporationist trend in New Zealand, expressed in the formation of one internally differentiated and highly inegalitarian society. The task of this socio-historical analysis is to explain why this turned out to be the case. The argument is made that two factors account for the divergent courses taken by the two societies in question: (1) the differing capacities of the indigenous people to respond to and shape the process of group encounter and conflict; and (2) the strategies adopted by settler and colonial forces in pursuit of their interests. These analytical factors provide a framework for discussing the historical processes of class structure formation and state formation in both Australian and New Zealand societies.

Beyond these historical frameworks, the paper explores how forces such as adaptability, territorial concentration, sociopolitical organization, attitudes toward religious syncretism, linguistic isolation, and inter-linguistic contacts have affected the capacities of these subaltern populations to retain independent identities and institutions, and thus experience exclusion/incorporation at the societal level. Also considered are how these forces affected the way Europeans perceived these groups and the subsequent strategies adopted by colonial and settler forces.

\section{Differential Racial Relations in Australia and New Zealand}

Perhaps more than any other single factor, the respective natures of pre-contact Aboriginal and Maori societies help to explain why Aboriginal and Maori relations with Europeans have been very different in the two countries. Aborigines and Maoris, according to their respective cultural mores, initially reacted in quite dissimilar ways to the arrival of European and European settlements in New Zealand and Australia, respectively. European treatment of Aborigines and Maoris reflected their perceptions of the indigenous cultures and to the native responses to "civilization." This article examines the differing characteristics of Aboriginal and Maori societies, which, respectively, facilitated or hindered an effective response to European colonization.

Maoris were better able to cope with the consequences of European settlement than Aborigines, and Europeans were less aggressive toward Maoris than Aborigines, partly because of the relative strength and resilience of Maori society. This is in no way to suggest that Maori culture was in any way superior or that Aboriginal culture was in any way "lacking" - each of the cultures must be examined in terms of their own environments and value systems. The goal here is to identify social and cultural characteristics that contribute to an understanding of why Aboriginal culture and society was largely destroyed by European settlement in the nineteenth century, and why Maori society and culture during the same period, while indeed damaged, remained essentially intact in significant ways.

The different patterns of race relations that developed in Australia and New Zealand may originate, to some extent, in the contrasting geophysical structures and climates of the two countries. Australia's continental expanse, flatness, vast arid regions, and climate extremes have meant that for most of the two centuries of European occupation, the settlers and Aborigines generally lived mutually exclusive lives. Such racial separateness was far less possible in New Zealand because of the country's smallness, ruggedness, and temperate climate. But the landscapes are, perhaps, even more significant, for, ultimately, they helped to determine the crucial characteristics of Maori and Aboriginal cultures discussed herein.

\section{Aborigine and Maori Pre-Contact Worldview}

Human habitation in Australia is ancient. At least 60,000 years ago, when Australia was joined by land bridges to New Guinea, the first people entered the area from somewhere in the South East Asian archipelago (Ryan 1981). By at least 30,000 years ago, prehistoric Aboriginal culture was well established. Whether it was a product of a single or a series of migrations, and to what extent it resulted from a blend of various ancient cultures or local cultural diffusion and evolution is still uncertain (Price 1972). In any event, the environment played a major role in the formation of Aboriginal culture and is partly responsible for this high degree of stability over the last 30,000 years. For example, the people of New Guinea, who probably shared the same ancestry with Aborigines, eventually became domesticators and cultivators, whereas Australia's climate and geography, unsuited to similar agricultural use, helped to ensure that Aborigines remained hunters, gatherers, and, therefore, nomads (Ward 1992).

New Zealand's earliest inhabitants came from eastern Polynesia about 1,200 years ago. These first settlers were apparently few in number and their culture developed in isolation, with probably no subsequent contact with Polynesia. Thus, Maori society had only about 1,000 years of pre-history in New Zealand, and during that time there had been swift 
cultural adaptation to the new environment (Belich 1986). Not only was Maori prehistory relatively short, it was characterized by innovation and rapid evolution, bringing it in sharp contrast with Aboriginal culture's longevity and stability. Consequently, Maori society was more flexible with potential for further adaptation to the changing circumstances of European arrival.

The essentially unchanging nature of Aboriginal society was reflected in the Aboriginal worldview: its beliefs and assumptions about the existence of the cosmos had been passed on, apparently largely unaltered, through countless generations. Such beliefs were not necessarily universally held, and were subject to local or regional interpretation, but at the risk of oversimplification, according to Ryan (1981) certain basic characteristics can be outlined.

Most tribes looked back to a time of creation when gods laid down the ground rules for all subsequent existence-the Dreamtime. From that time, Aborigines acted out their lives on a great cosmic stage with a prepared script. All life, past, present, and future, was omnipresent. Man's duty was to duplicate the sacred past, for the Dreamtime had set the precedent for all human behavior forever. Aboriginal society emphasized the status quo and emotional satisfaction derived from the Dreamtime. They achieved a balance with their natural environment, neither dominating nor being dominated by it. They saw no need to change the relationships with the world around them (Ryan 1981).

Maoris similarly looked back to a time of creation by deities, but they had no equivalent to the Dreamtime. Where Aborigines were concerned with fulfilling the wishes of their spiritual predecessors, the gods and spirits to whom Maoris paid homage were expected to work for them, and to assist and protect them. From a comparative point of view, Maori religion was more utilitarian and less concerned with metaphysical absolutes than was Aboriginal religion. (Belich 1986). Maori beliefs were also less entrenched in precedent. Thus, if the new Christian god was as powerful and benevolent as the missionaries claimed, then Maoris could add him to their own deities without too much trouble-once they agreed to do so. Such a decision was unthinkable for the Aborigines, for the new beliefs could in no way be reconciled with the allembracing and complete values of the Dreamtime. Most Maoris had declared their allegiance to Christianity by the 1860s, whereas very few Aborigines had done so, and that served to facilitate communications between Maoris and Europeans.

For both Maoris and Aborigines, land ultimately belonged to the tribe and was a source of physical well-being as well as emotional and spiritual strength. In New Zealand's later pre-contact period, land was a common, and perhaps major, source of conflict, probably due to substantial increases in the Maori population. Unlike Australia, land in New Zealand was subject to conquest, and military strength ultimately decided ownership. Thus, warfare was a predominant feature of Maori life, in contrast to sporadic Aboriginal skirmishing. Maori society was geared for war. There were large and sophisticated pa (fortified settlements), and each hapu (localized extended families) had its war party. Children indulged in war games from an early age because courageous warriors were highly respected. A good deal of fighting consisted of ambushing and localized skirmishing, but it could also be on a much larger scale, sometimes involving thousands of warriors in a regional campaign. Thus, Maori military resources and strategies were more effective in opposing European settlement than were Aboriginal tactics. iii Maoris had a war machine, which could only be subdued by 10,000 Imperial troops in the 1860s, while on the Australian outback Aborigines could usually be 'dispersed' by small numbers of armed horsemen (Price 1972).

\section{INDIGENOUS DEMOGRAPHIES}

Aboriginal culture had no agriculture or domestic animals. Aborigines foraged, gathered, hunted, and fished, moving their small campsites according to the availability of berries, roots, seeds, insects, reptiles, fish, and marsupials. (Ryan 1981). All but the most essential possessions were a nuisance and irrelevant for a highly mobile existence. Except in the more southerly regions, no clothes were worn, and 'huts' were, at most, bark or shrub windbreaks. Tools consisted of multipurpose stones, sticks, spears, and boomerangs. These were simple, but highly functional, and adequate for Aboriginal needs. Aborigines initially had no desire for any item of European material culture. They were a non-acquisitive, nonmaterialistic, nomadic people (Price 1972).

Maoris were fairly mobile within their tribal regions, but led a far more settled life than Aborigines. Maoris built substantial houses in well-populated villages, and while Maoris also gathered and scavenged food, they were also expert agriculturalists and horticulturists (Belich 1986). Thus, it was easier for Europeans to communicate and deal with Maoris who lived in settlements than with the scattered, nomadic Aborigines. Further, Europeans considered Maori agricultural activities meaningful and useful, and accordingly 'superior' to Aboriginal scavenging.

In 1788, when European settlement was established in Australia, there were about 300,000 Aborigines scattered widely across the continent (Ward 1992). In New Zealand, Maoris were estimated at 200,000 to 250,000 in 1769 (Belich 1986). Three-quarters of them lived in the northern half of the North Island, creating a high density of population. In further contrast to Australia, it was not until the late 1860s that Maoris were finally outnumbered by European settlers. Such considerations naturally helped to determine the respective priorities of the colonizers in Australia and New Zealand. Aborigines were also disadvantaged by the multiplicity of their languages_over 200, with varying patterns of mutual intelligibility, hindering communication, not only among themselves, but with Europeans as well (Price 1972). Maoris on the other hand, spoke only one language, which was virtually universal throughout eastern Polynesia.

In the late eighteenth century, there were some five hundred Aboriginal tribes, each with its own name, territory, identity, history, and mythology. There was, however, little political cohesion. Tribes were relatively unstructured organizations based on real or alleged kin networks (Ryan 1981). There was no paramount chief or structured hierarchy, as was common throughout Polynesia. Tribal groups seldom acted in collaboration. The principal entities were small clusters of extended families, which, while identifying with the larger tribal unit and meeting with it at certain times, roamed the 
countryside alone, usually in groups of fewer than twenty. The resources for settlement life, particularly on an agricultural basis, simply did not exist (Ryan 1981). The Maori also formed tribes, however Maori tribes, being fewer in number than their Australian counterparts (at around 50 tribes), contained many more members, even thousands in some cases (Howe 1977).

\section{PRE-CONTACT SOCIAL ORGANIZATION}

Even with all of the differences described above, however, the major differences between Maori and Aboriginal culture and social organization relate to social stratification and the nature of leadership. Maori society was typically Polynesian in that it was hierarchical and rigidly stratified. Each tribe consisted of chiefs of various ranks, other 'nobles,' commoners who formed the bulk of the population, and, finally, slaves. In contrast, Aborigines had virtually no social hierarchy or stratification. There were no paramount chiefs and 'government' was largely information and usually in the hands of the elders in each family, or, less commonly, a tribal council.

Overall, Aboriginal society seems to have been organized to achieve and maintain order by methods of resolving conflict peacefully rather than exacerbating it. The most obvious explanation for this is that the rigors of a nomadic life in a lessthan-bountiful landscape made the raising and provisioning of armies, as well as the indulgence in armed campaigns, too demanding. Also, cooperation and a high degree of harmony were essential for Aboriginal survival (Ryan 1981). In short, there were limitations to the ways in which Europeans could treat Maoris, where such limitations were mostly absent in the Australian colonies. Highlighting these differences does not imply that settlers and governments in New Zealand were more enlightened on issues of race than their Australian counterparts. However, there were certain features of settlement that were distinct to each country, and these also partly account for the different developments in race relations.

\section{BRITISH COLONIZATION AND ANNEXATION}

British colonization of Australia began in 1788 with the establishment of a penal settlement in New South Wales; British annexation of New Zealand came more than a hal-century later with the Treaty of Waitangi iv in 1840. As it turns out, these respective times and motives for settlement had an important bearing on race relations. Early European settlements in New South Wales had little concern about the Aboriginal populations, mainly due to: 1) the particular aims of the penal settlement administrators; 2) the early years of severe economic hardship; and 3) the fact that Aborigines posed relatively little threat and quickly proved to be of little economic use.

By contrast, early colonial administrators in New Zealand were preoccupied with Maori matters. In the 1840s, humanitarian thinking had a major impact on newly-established colonial governments, $v$ and Maoris simply could not be ignored (Howe 1977). They had an overwhelming numerical and potential military superiority, together with an essential role in European commercial interest in whaling, flax, and timber. Further, Maoris were considered the owners of land in New Zealand, whereas land in Australia was considered to be in waste and British by right of occupation. Land was taken from the Aborigines by settlers and the Crown alike, on the basis of default. In New Zealand, only the Crown could purchase land from Maoris. Thus, another major reason why administrators had to be concerned with the Maori population was because the opening of the country for settlement depended on the success of government officials in encouraging Maoris to sell their lands. In the early years of settlement across Australia, land was for the settlers' taking (Price 1972).

In addition to the importance of geography in the formation of indigenous cultures in Australia and New Zealand, geography had an additional influence on race relations. Once they crossed over the Blue Mountains in 1813, Australian settlers found few barriers, except for resources, climate, and distance, to the widespread penetration of the continent, especially to the expansion of the pastoral economy, the gold rushes, and the exponential growth in the migrant population (Ward 1992). In most Australian colonies, settlement tended to precede effective government and once colonial administrations had been established, immense distance and rudimentary means of communication usually meant that actual government control was absent or minimal, at best. In New Zealand, the rugged landscape together with Maori ownership of the land and the policy of Crown preemption, tended to keep European settlement concentrated in a few towns in each region. Governments in New Zealand had much greater opportunity to control settler actions and far more inclination to do so because of the strong influence of humanitarian principles. Thus, although the migrants flooding into Australia and New Zealand in the 1840s and 1850s tended to share common origins, ambitions, and hostile attitudes towards the native inhabitants, settlers in New Zealand had less opportunity to put their racial views into practice. However, it can be argued that perhaps even more important than these ideological, political, and demographic, and geographic considerations, is the way in which the social organization and habits of the indigenous societies influenced colonizers attitudes and policies (Howe 1977).

Thus, the long-term implications of Europeans' initial interpretation of Maori and Aboriginal societies cannot be overstated. Maoris, because of their socio-political organization, settlement patterns, and use of resources, were considered to be a sovereign people, whereas Aboriginal society lacked the essential European conditions for such sovereignty. No consideration was ever given to negotiating with Aborigines for the purchase or transfer of land. No treaty was ever signed with them because Aborigines offered no united front to oppose the alienation of the land and they had no villages or plantations to defend. Even to the present, Aborigines are unable to establish a legal case for title to their former tribal lands because, unlike Maoris or some native North Americans, they have no treaty to invoke to support a claim for tribal land rights.

In New Zealand, negotiations over annexation were based on the assumption that Maoris were a sovereign people. The documentation of annexation, the Treaty Of Waitangi, provided that this sovereignty was to be transferred to the crown and, in return, Maoris were promised full, exclusive, and undisputed possession of their lands and estates, forests, 
fisheries, and other properties. For most of the next twenty years, Crown pre-emption effectively provided Maoris with double protection: land had to be purchased from them and, if they were willing to sell, only the Crown could do the purchasing. Aborigines had neither protection.

Considerations of sovereignty also had a bearing on the legal status of Maoris and Aborigines. In both countries, the indigenous people were declared British subjects with the advent of colonization. Yet, Aborigines were given few actual rights, least of all to their lands, which, in terms of their physical and emotional survival, were a crucial element of their culture. Aboriginal legal status dwindled from 1788 and, over time, their low social standing was written into government regulations. Official sanction was accorded to a brutal 'frontier justice': violent reprisals by European settlers prevailed in all the Australian colonies until Aborigines were either totally exterminated, as in Tasmania (Robson 1985), or subdued, heavily depopulated, and confined to the least desirable areas of the content. Aborigines had none of the rights of British subjects. The legal standing of Maoris was different. In the first decades of colonization, various governors went so far as to modify aspects of English law for Maoris living beyond the European settlements and to incorporate some traditional Maori institutions and concepts of legal administration.

\section{THE EXTENSION OF THE FRONTIER AND THE TRAJECTORY OF RACE RELATIONS}

The rapid extension of colonial frontiers during the last part of the nineteenth century served to solidify the trajectory of race relations in the two countries. By 1900, Europeans had undisputed domination over the indigenous inhabitants of both colonies. Both Maoris and Aborigines were relegated to the role of subservient, underprivileged racial minorities. Aborigines had lost claim to all of their tribal lands and Maoris had legal rights to only 4.5 million hectares out of an original 27 million (Howe 1977). In addition, both of these populations were declining dramatically numerically. Yet, in spite of such common processes, the respective patterns of race relations in the two countries continued to follow separate courses. In New Zealand, policies for racial amalgamation were still the order of the day (Spoonley 1991), whereas, in Australia, they had been abandoned in favor of restrictive legislation for Aborigines

In the 1860s, Europeans launched a major war against the central North Island Maoris. Such a large-scale campaign against Aborigines was impossible and unnecessary because they were seen as widely-scattered rural pests rather than sovereign people. But the war against Maoris from 1863 to 1866 required an extended and fierce British military campaign (Spoonley 1991). Only after several years with many casualties on both sides were the Maori eventually defeated. Soldiers, particularly British officers, made many favorable comments about the courage, valor, and military prowess of Maori fighters. In addition, the administrators responsible for the conduct of war, contrary to the express demands of a majority of the settlers, were determined that it not be a war of extermination, either in fact or intention. They sought to crush central North Island Maori attempts at independence, to overturn their reluctance to open their lands to further European settlement, and to reverse their opposition to accepting 'British law and order.' The war was to insure that Europeans would predominate in New Zealand and Maoris would be 'civilized,' by force if necessary. Maoris were not to be destroyed but were to be forced to accept citizenship, and be included in, rather than excluded from, the dominant culture. For these reasons, the war was selective. Not all Maoris were enemies of the state power, only those who blatantly rejected the Queen's sovereignty. A good many Maoris elsewhere in New Zealand either remained neutral, or supported and sometimes sided actively with government troops, depending on the complex subtleties of long-standing inter-tribal rivalries (Belich 1986).

Incorporationist thinking in the New Zealand government was so strong that, at the time when Maoris were suffering severe military defeat at the hands of the British and their lands were being opened to European settlement, they were simultaneously being given major legal rights. As the legal status of Aborigines declined significantly, the relatively high legal standing of Maoris, at least in theory, was continually reinforced, to the general disgust of settlers, whose actions, if not racist attitudes, were still held in check by geography and the effectiveness of legal sanctions (Belich 1986). In 1865, the Native Rights Act gave statutory recognition to the principle of the Treaty of Waitangi, which declared Maoris to be British subjects. The 1867, the Maori Representation Act established four Maori electorates for the country and gave the vote to all Maori males, twelve years before property qualifications for European male franchise were lifted. Further, in 1867, the Native Schools Act attempted to provide something of a state system of education in outlying districts: Maori parents supplied land and some financing, and the government provided teachers and additional funding. The schools were not racially segregated and both European and Maori children were encouraged to attend (Spoonley 1991).

Thus, policies for Maoris and Aborigines continued to differ noticeably_those in New Zealand directed toward inclusion, those in Australian colonies to exclusion and even extermination. They did so largely as a result of the respective responses of the indigenous societies to the further extension of the frontier. Aborigines continued to resist settler penetration of their lands, but there was little they could do to alleviate their position. During the last part of the nineteenth century, the administrations of the Australian colonies (with the obvious exception of Tasmania) adopted 'protective' legislation, replacing previous policies of 'dispersal.' The underlying justification for these new policies was that Aborigines had been unable to deal with the colonization and civilization and were doomed to extinction (Ward 1992).

From the outset, contacts among Aborigines, convicts, administrative personnel, and, later, emancipated convicts, and free settlers created a tension whose legacy was to inform race relations generally. Indeed according to King-Boyes,

It would be difficult to find two cultures of greater contrast than the European and the Aboriginal; the former exploitative and competitive, the latter conservationist and cooperative. Even without the problems posed by differences in language, technology, and external appearances, it is doubtful that a meaningful dialogue could have been established between the two people for their aspirations were diametrically opposed. (King-Boyes 1977) 
Indeed, Aborigines were regarded not only as primitive, but also useless. Under the impact of European contact, their personal and social denigration cultivated an image of Aborigines as disposable subordination. It was this image of the Aborigines which, with the end of convict transportation by the mid-nineteenth century, caused labor shortages that induced the importation of cheap, indentured labor, especially Chinese.

\section{NATION STATE CREATION AND WHITENESS}

When the six Australian colonies became a Federation in 1901, the Constitution made only two references to Aborigines One section (\#127) of the Constitution excluded Aborigines from the census (although heads of cattle were counted) vi and another section (\#51) gave power over Aborigines to the States rather than to the Federal Government. Federal policy, as it turns out was much more concerned with the so-called "Yellow Peril," in reference to the Chinese.

Chinese immigrants started arriving after the Australian gold rush of the early 1850s, and their appearance created alarm amongst white settlers. In 1856, the colony of Victoria formally passed a law prohibiting Chinese persons from entering its territory. The Victoria Chinese exclusion law was then taken up by the other five colonies in Australia and extended to include all non-Whites everywhere. This policy of excluding all immigrants except those belonging to the white race became known formally as the "White Australia Policy" and had the overwhelming support of all the colonial settlers.

In fact, it was the common acceptance of the White Australia policy that drew the various and (historically unaligned) colonies of Australia into political unity because it highlighted the need for common immigration laws. The establishment of trade unions and organized labor movements also created a need for common social policies in other areas as well, and, by 1898 , representatives from all the colonies had thrashed out a common political structure. The Commonwealth of Australia was given official sanction by the British Parliament in 1900 and was implemented on 1 January 1901. Thus, the central government, created on a federal system based on the American model, established the maintenance of the White Australia policy as one of its first priorities (Ward 1992).

Likewise, in New Zealand, as the nation-state and nationalism cohered in the last decades of the nineteenth century, legislative controls also began to be imposed on who could and could not enter New Zealand and become citizens. These controls involved selecting for a variety of characteristics which were deemed desirable and therefore wanted in the citizenry. While various groups were subject to various controls, the relatively small number of Chinese were principally targeted by what came to be called, by its advocates at the time, the 'White New Zealand' policy. In the last two decades of the nineteenth century and first two of the twentieth, New Zealand passed a series of increasingly restrictive laws directed primarily at the Chinese, although there was never an official 'White New Zealand' policy as in Australia. While this article does not endeavor to examine racial thinking as applied to various minority groups at the time in New Zealand, the notably different attitudes towards the Maori and the Chinese are notable.

\section{CONCLUSION}

Conflicts, or any other type of social interaction, by definition, involve more than one side. Most often, however, scholars have implicitly, if not always explicitly, assumed that in order to understand the nature, direction, and outcomes of conflict situations, it is enough to observe the dominant side-its interests, capacities, concerns, and strategies. This tendency is apparent in many studies of colonial processes that relegate indigenous people to be physically present (or absent) in a given territory, without acknowledging their role in acting, reacting, and otherwise shaping the nature of the societies in question.

The general point with regard to the study of social history, and which is illustrated by the cases of Australia and New Zealand, is the need for historical perspective that looks at history as an open-ended process that neither leads in any necessary direction nor has predetermined goals and outcomes. One of the methodological fallacies in historical studies of race relations is teleology, the assumption, whether explicit or otherwise, that what happened occurred in a particular way because of the inexorable logic of some supra-historical force, whether the unfolding of the race relations cycle or the dynamics of migrant superordination/ subordination differentiation.

In rejecting this logic, this article attempts to demonstrate that the racial conflicts in Australia and New Zealand did not follow a course determined from the outset by their essential nature as settler-colonial societies, capitalist economies, racial orders, or any other labels that might be attributed to these societies. The incorporationist and exclusionary dynamics detected in the formation of these societies were not the inevitable products of the clash between settlers and indigenous people or between pre-capitalist and capitalist modes of production. Rather, these outcomes are best seen as results of multiple factors whose specific combinations cannot be directly derived from the general characteristics that these societies share among themselves, and, perhaps, also with others

Thus, Australia and New Zealand illustrate the importance of contextual specificity and taking indigenous capacities into account. When considering the process of colonization, there tends to be an emphasis on the 'European side' of the equation, seeing the various colonizers ideas and initiatives as the major determinants of any differences in colonial histories. However, this analysis suggests that differing attitudes and policies for Aborigines and Maoris were due less to dissimilarities in basic European philosophies and social attitudes in Australia and New Zealand than to a series of influences unique to each country, particularly geographic realties; their impact on the character of the indigenous populations and the strategies available to colonial administrations and settlers. 


\section{ENDNOTES}

\footnotetext{
${ }^{1}$ Throughout the text the term 'race' is used as a socially-constructed concept. Racial differences, i.e. patterns of phenotypical variation, are invested with particular social significance in specific contexts.

${ }^{2}$ This is not meant to imply that Maori society and culture was unaffected by colonization. Indeed, the Maori population suffered greatly at the hands of the British. However, a comparative analysis of Euro-Maori relations and Euro-Aboriginal relations illustrates salient differences.

${ }^{3}$ It is important to note here the strong evidence that there was a long and protracted guerilla war in Australia, a war that used many tactics, including: destruction of food sources; disruption of lines of supply and communication; spying; negotiating; killing the enemy; stealing food to deprive the enemy, and provide for their own people when energy was used for meetings and fighting instead of hunting and gathering; stealing and learning to use European weapons; humiliating and demoralizing the enemy; not cooperating with Europeans; and being generally disruptive.

${ }^{4}$ The Treaty gave Māori sovereignty over their lands and possessions and all of the rights of British citizens. What it gave the British in return depends on the language-version of the Treaty that is referred to. The English version can be said to give the British Crown sovereignty over New Zealand but in the Māori version the Crown receives kawanatanga, which, arguably, is a lesser power. Dispute over the true meaning and the intent of either party remains an issue (Belich 1986).

${ }^{5}$ The administration of New South Wales also felt this humanitarian influence, but insistence on the humanity of the Aborigines, and on the concept of equality before the law, could not reverse doctrine entrenched since 1788, and, in fact, this period is a time in which racial prejudice in the colony came to a peak.

${ }^{6}$ This was the situation until the referendum of 1967 when an overwhelming majority of Australians voted to include Aborigines in the census of their own country.
}

\section{REFERENCES}

1. American Indian Lawyer Training Program, \& Indian Resources Institute (U.S.). (1987). Indian tribes as sovereign governments. Oakland, CA: American Indian Resources Institute.

2. Banton, M. (1967). Race Relations. London: Tavistock.

3. Belich, J. (1986). The Maori, the British and the New Zealand Wars. Auckland: Auckland University Press.

4. Berry, B. \& Tischler, H. L. (1978). Race and Ethnic Relations. Boston: Houghton Mifflin.

5. Blalock, H. (1967). Toward a theory of minority group relations. New York: Capricorn.

6. Degler, C. (1970). Neither Black nor White: Slavery and Race Relations in Brazil and the United States. Madison: University of Wisconsin Press.

7. Fixico, D. (1986). Termination and Relocation: Federal Indian Policy 1945-1960. Albuquerque: University of New Mexico.

8. Frazier, F. (1957). Race and Culture Contacts in the Modern World. New York: Knopf.

9. Graham, R (ed.). (1990). The Idea of Race in Latin America 1870-1940. Austin: University of Texas.

10. Green, R \& Tonneson, T. (eds.) (1991). American Indians: Social Justice and Public Policy. Madison: University of Wisconsin.

11. Greenstein, R. (1995). Genealogies of Conflict: Class, Identity and State in Palestine/lsrael and South Africa. Wesleyan University Press.

12. Kinloch, G. (1974). The Dynamics of Race Relations: A Sociological Analysis. New York: McGraw-Hill.

13. King-Boyes, M. (1977) Patterns of Aboriginal Culture: Then and Now . Sydney:McGraw-Hill

14. Lazewski, A. (1976). American Indian Migration to and within Chicago. PhD Dissertation. University of IllinoisChampaign/Urbana.

15. Lewis, G. (1985). The Contemporary Caribbean: A General Overview. Washington: Wilson Center.

16. Luhman, R \& Gilman, S. (1980). Race and Ethnic Relations: The Social and Political Experience of Minority Groups. Belmont, CA: Wadsworth.

17. Newman, J \& Matzke, G. (1984). Population: Patterns, Dynamics, and Prospects. New Jersey: Prentice Hall.

18. Price, A.G. (1972). Island Continent: Aspects of the Historical Geography of Australia and its Territories. Sydney: Angus and Robertson.

19. Mason, P. (1970). Patterns of Dominance. London: Oxford University. 
20. Robson, L. (1985). A Short History of Tasmania. Melbourne: Oxford University.

21. Ryan, Lyndall. (1981). The Aborigines. Vancouver: University of British Columbia.

22. Schermerhorn, R.A. (1970). Comparative Ethnic Relations. New York: Random House.

23. Sigler, J. (ed.) (1987). International Handbook on Race Relations. New York: Greenwood Press.

24. Spoonley, P. (1991). Nga Take. Ethic Relations in Aotearoa/New Zealand: Dunmore Press.

25. Ward, R. (1992). Concise History of Australia. Queensland: University of Queensland.

26. Wolf, E and Hansen E. (1972). The Human Condition in Latin America. New York: Oxford University Press.

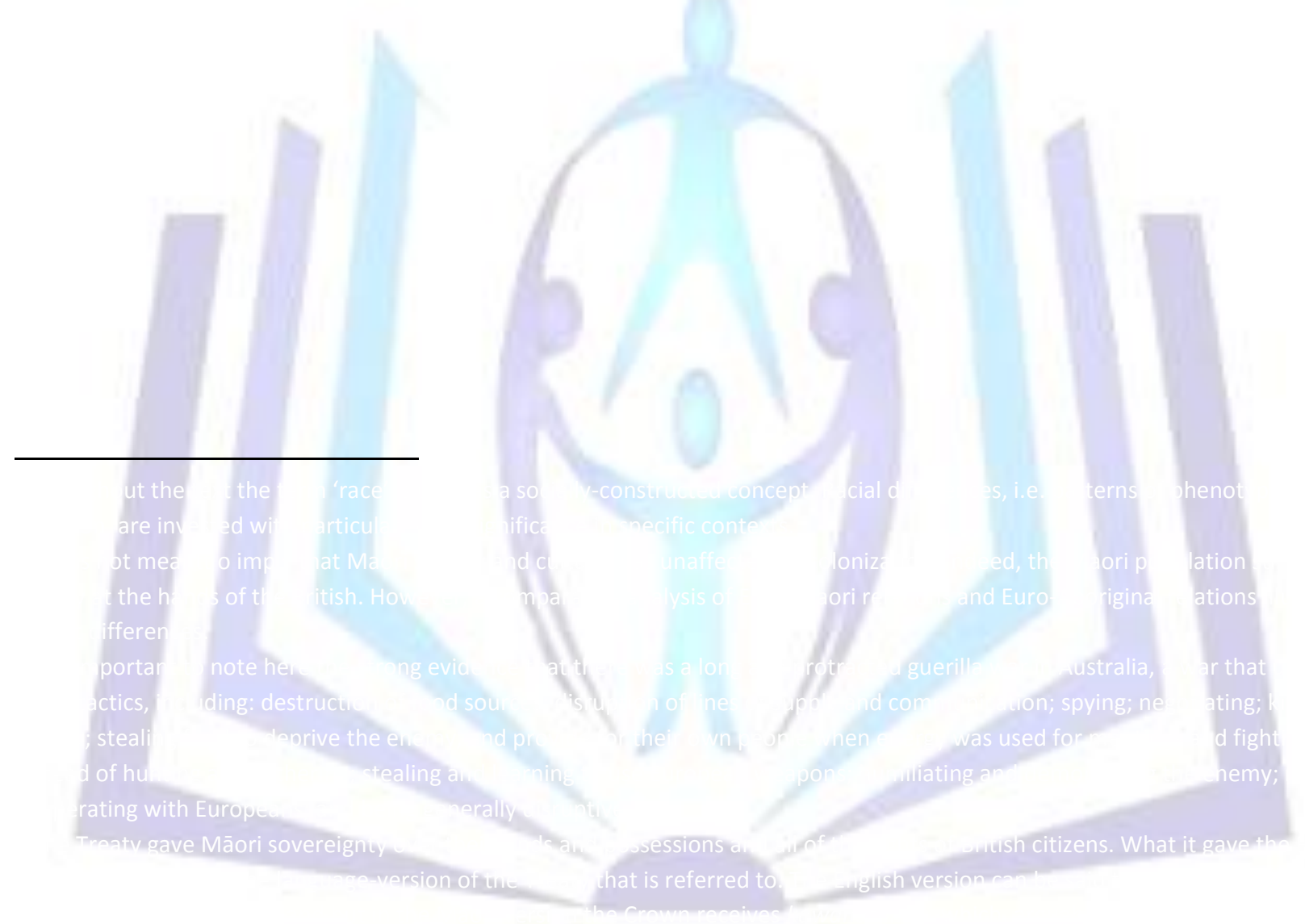

